\title{
Evaluating Evolutionary Constraint on the Rapidly Evolving Gene matK Using Protein Composition
}

\author{
Michelle M. Barthet · Khidir W. Hilu
}

Published online: 27 June 2008

(C) Springer Science+Business Media, LLC 2008

Erratum to: J Mol Evol (2008) 66:85-97

DOI 10.1007/s00239-007-9060-6

In the online and printed version of this article, the footnote containing a link to supplementary material was not included. It is located below.

The online version of the original article can be found under doi: 10.1007/s00239-007-9060-6.

Electronic supplementary material The online version of this article (doi:10.1007/s00239-008-9129-x) contains supplementary material, which is available to authorized users.

M. M. Barthet · K. W. Hilu

Department of Biological Sciences, Virginia Tech, Blacksburg,

VA 24061, USA

M. M. Barthet $(\bowtie)$

School of Biological Sciences, University of Sydney, Sydney,

NSW 2006, Australia

e-mail: michelle.barthet@bio.usyd.edu.au 